\title{
"Hail the Census Night": Trust and Political Imagination in the 1960 Population Census of Ghana
}

\author{
GERARDO SERRA \\ Nantes Institute for Advanced Study
}

\author{
Under Powerful Fluorescent Lights \\ Young Ghanaians write in a book of gold [...] \\ With smiles on their lips they ask: \\ Where did you sleep the night before? \\ How old are you \\ What is your name? \\ Answer! [...] \\ And save Ghana from Economic Want \\ And kill poverty and illiteracy \\ Hail the Census Night. \\ “Census Night," anonymous poem in Evening News, 20 Mar. 1960.
}

\section{INTR ODUCTION}

In the early 1960s Africa was rife with hopes. For the newly independent states, the collection, construction, and dissemination of statistics came to be seen as an important precondition of economic and social modernization. As the first colony in Sub-Saharan Africa to gain independence from British rule, in March 1957, Ghana incarnated the hopes of the continent. Between 1957 and 1966, when a military coup put an end to the rule of Kwame Nkrumah, the state embarked on a radical attempt to expand the provision of health and

Acknowledgments: Previous versions of this paper were presented at the $41^{\text {st }}$ Annual Meeting of the History of Economics Society (Université du Québec à Montréal, 2014), the annual meeting of the African Economic History Network (London School of Economics, 2014), the "Figuring Disparity: The Measurement of Inequality in Historical Perspective" workshop (University of Cambridge, 2015), the "Development by Indicators: Knowledge and Governance" workshop (Nantes Institute for Advanced Study, 2015), and the 18th World Economic History Congress (Kyoto, 2015). Besides the organizers and participants to these events, and the anonymous CSSH reviewers, I would like to thank Catherine Boone, Leigh Gardner, Martha Lampland, Mary Morgan, and Jacob Norris for their helpful comments. All errors remain my responsibility. 
education, and guide the transformation of the country from a cocoa exporter to a planned and industrialized economy. ${ }^{1}$ The 1960 Population Census of Ghana was expected to play an important role in making this possible. ${ }^{2}$ Shortly before the enumeration began, Nkrumah declared on the radio:

My Government attaches the very greatest importance to the successful outcome of this operation, the first census since Ghana became independent.... The Government needs to know how many people there are in the country and the structure of the population in order to enable it to organize its development plans and services in accordance with the manpower resources of the country. ${ }^{3}$

The census took place at an ambivalent juncture in Ghana's political history, when the Convention People's Party, which had led the country to independence, was experiencing the transition from "mass party" to authoritarian regime. ${ }^{4}$ Although Ghana was formally declared a one-party state only in 1964 in the aftermath of a referendum that disbanded all political opposition, by the early 1960 s the signs were growing of an authoritarian transformation. ${ }^{5}$ This could be seen, for example, in the frequent application of the Preventive Detention Act, passed in 1958 and reinforced through successive amendments in 1962 and 1963, which allowed imprisonment of those suspected of anti-

1 On Ghana's attempted economic transformation and the reasons behind its failure, see Tony Killick, Development Economics in Action: A Study of Economic Policies in Ghana (London, 1978).

${ }^{2}$ Ghana Census Office, The 1960 Population Census of Ghana, 7 vols. (Accra, 1962-1971): vol. I: The Gazetteer: Alphabetical List of Localities with Number of Population and Houses (Accra, 1962); vol. II: Statistics of Localities and Enumeration Areas-Sex, Age, Birthplace, School Attendance and Economic Activities (Accra, 1962); Advance Report of Volumes III and IV-Demographic and Economic Characteristics of Regions (based on a 10 Percent Sample) (Accra, 1962); vol. III: Demographic Characteristics of Local Authorities, Regions and Total Country -Sex, Age, School Attendance of Local and Foreign Origin Populations (Accra, 1964); vol. IV: Economic Characteristics of Local Authorities, Regions and Total Country-Type of Activity, Industry, Occupation and Employment Status of Total and Foreign Origins Population (Accra, 1964); vol. V: General Report (Accra, 1964); vol. VI: The Post-Enumeration Survey (P.E.S.) Supplementary Enquiry (Accra, 1971). The main inquiry was supplemented by a series of monographs dealing with specific aspects: Ghana Census Office, The 1960 Population Census of Ghana, Special Report (A-E) (5 vols.) (Accra 1963-1964): Special Report 'A': Statistics of Towns with 10,000 Population or More (Accra, 1964); Special Report 'B': Socio-Economic Indices of Enumeration Areas (Accra, 1963); Special Report ' $C$ ': Data for New Regions (Accra, 1963); Special Report 'D': List of Localities by Local Authority, Arranged in Order of Geographic Code Number and Showing the Number of Population and Houses (Accra, 1963); Special Report 'E': Tribes in Ghana. (Accra, 1964).

3 Kwame Nkrumah, "Census Night, Accra, March 20 th 1960 ," in Samuel Obeng, ed., Collected Speeches of Kwame Nkrumah, 2 vols. (Accra, 1997), vol. 1, 42.

4 In the West African context the distinction between the two was not necessarily so clear-cut, and political scientists repeatedly pointed out that one-party states could emerge as the outcome of democratic processes. See, for example, Ruth Schachter's classic, "Single Party Systems in West Africa," American Political Science Review 55, 2 (1961): 294-307.

5 On these developments, see Dennis Austin, Politics in Ghana, 1946-1960 (Oxford, 1970), 387-421; Trevor Jones, Ghana's First Republic (1960-1966): The Pursuit of the Political Kingdom (London, 1976); K. B. Ayensu and S. N. Darkwa, The Evolution of Parliament in Ghana (Legon, 2006). 
government activities for up to five years without charge or trial. ${ }^{6}$ The press was placed under the direct control of government-appointed censors, while universities were being purged of "neocolonial" and "reactionary" elements. Based on archival sources collected in Ghana and Britain, this article uses census propaganda as a case study to reexamine the relationship between the iconographies and the practices underpinning the construction of statistical knowledge and the process of imagining and building the postcolonial state.

As a landmark of state sovereignty, census-taking has been central in the reflections of historians and sociologists concerned with processes of state formation. Since the nineteenth century, census-taking has usually been located at the intersection of "the political project of developing the administrative infrastructure and authority of a modern state, the cultural project of constructing the communal bonds ... of a modern nation, and the scientific project of producing useful knowledge about the population." 8 Not only does the census occupy a central role in the making of Benedict Anderson's "imagined communities" but, most notably since Michel Foucault's influential analysis of "governmentality" and "biopolitics," demographic statistics has emerged as a rich site for analyzing the connections between state knowledge, bureaucratic power, and population as an object of governance. ${ }^{9}$ Census-taking also fits neatly into James Scott's account of how states, through the imposition of simplified conceptual grids, make societies "legible" and transform them into objects of policy intervention. ${ }^{10}$ Building on these insights, historians, sociologists, and anthropologists have analyzed the political implications of census-taking in a variety of contexts, including Italy, Germany, Canada, United States, India, Brazil, and Israel. ${ }^{11}$ Despite substantial differences, all of these studies share

${ }^{6}$ For vehement denunciations of the Preventive Detention Act and political detention, see T. Peter Omari, Kwame Nkrumah: The Anatomy of an African Dictatorship (Accra, 2009), 70-78; and K. Kesse-Adu, The Politics of Political Detention (Tema, 1971).

7 P.A.V. Ansah, "Kwame Nkrumah and the Mass Media," in Kwame Arhin, ed., The Life and Work of Kwame Nkrumah: Papers of a Symposium Organized by the Institute of African Studies University of Ghana, Legon (Accra, 1991), 88-107; Francis Agbodeka, A History of University of Ghana: Half a Century of Higher Education (1948-1998) (Accra, 1998), ch. 8.

8 Mara Loveman, "Race to Progress: Census Taking and Nation Making in Brazil (1870-1920)," Hispanic American Historical Review 89, 3 (2009): 438-39. For a comparative perspective on statistics and administrative development in nineteenth-century Europe, see Stuart Woolf, "Statistics and the Modern State," Comparative Studies in Society and History, 31, 3 (1989): 588-604.

9 Benedict Anderson, Imagined Communities: Reflections on the Origin and Spread of Nationalism (London, 2006), 164-70; Michel Foucault, Security, Territory, Population: Lectures at the College de France, 1977-1978 (Basingstoke, 2007); Michel Foucault, The Birth of Biopolitics: Lectures at the College de France, 1978-1979 (Basingstoke, 2008).

10 James Scott, Seeing like a State: How Certain Schemes to Improve the Human Condition Have Failed (New Haven, 1998).

11 See, respectively, Silvana Patriarca, Numbers and Nationhood: Writing Statistics in Nineteenth Century Italy (Cambridge, 2003); Götz Aly and Karl Heinz Roth, The Nazi Census: Identification and Control in the Third Reich (Philadelphia, 2004); Bruce Curtis, The Politics of Population: State Formation, Statistics and the Census of Canada, 1840-1875 (Toronto, 2001); Margo Anderson, The American Census: A Social History (New Haven, 1988); Arjun Appadurai, 
the insight that the census does not simply describe an already existing reality, but plays an active role in its construction and consolidation.

Although several studies of census-taking in Rwanda, Burundi, and especially Nigeria raise important questions regarding the legacies of colonialism and ethnic politics, census-taking has not figured prominently in analyses of state-building in postcolonial Africa. ${ }^{12}$ This is unfortunate for reasons that are related to both the evolution of African states in the long-run and the specificities of postcolonial politics. With reference to the former, Jeffrey Herbst claimed that the most striking continuity in African state-building is that "almost all leaders have had to confront the problem of low population densities, which have made it expensive to control people as distance from the capital increases relative to areas with higher population densities."13 From this viewpoint, census-taking can be seen as a historically situated instrument that could quantify colonial and postcolonial rulers" "wealth over people.",14

\footnotetext{
"Number in the Colonial Imagination," in Carol A. Breckenridge and Peter van der Veer, eds., Orientalism and the Postcolonial Predicament (Philadelphia, 1993), 314-39; Loveman, "Race to Progress"; Anat Leibler and Daniel Breslau, "The Uncounted: Citizenship and Exclusion in the Israeli Census of 1948," Ethnic and Racial Studies 28, 5 (2005): 880-902.

12 On Rwanda and Burundi, see Peter Uvin, "On Counting, Categorizing, and Violence in Burundi and Rwanda," in David I. Kertzer and Dominique Arel, eds., Census and Identity: The Politics of Race, Ethnicity, and Language in National Censuses (Cambridge, 2002), 148-75. On the troubled history of Nigerian census-taking, see S. A. Aluko, "How Many Nigerians? An Analysis of Nigeria's Census Problems, 1901-1963," Journal of Modern African Studies 3, 3 (1965): 37192; Babatunde A. Ahonsi, "Deliberate Falsification and Census Data in Nigeria," African Affairs 87, 349 (1988): 553-62; Ita Inyang Ekanem, The 1963 Nigerian Census: A Critical Appraisal (Benin City, 1972); Morten Jerven, Poor Numbers: How We Are Misled by African Development Statistics and What to Do about It (Ithaca, 2013), 56-61; Abraham Okolo, "The Nigerian Census: Problems and Prospects," American Statistician 53, 4 (1999): 321-25. Discussions of census-taking have been more common in the history of colonial Africa. Recent examples include: Dmitri van den Bersselaar, "Establishing the Facts: P. A. Talbot and the 1921 Census of Nigeria," History in Africa 31 (2004): 69-102; John C. Cinnamon, "Counting and Recounting: Dislocation, Colonial Demography, and Historical Memory in Northern Gabon," in Karl Ittman, Dennis D. Cordell, and Gregory H. Maddox, eds., The Demographics of Empire: The Colonial Order and the Creation of Knowledge (Athens, Oh., 2010), 130-56; and Keren Weitzberg, "The Unaccountable Census: Colonial Enumeration and Its Implications for the Somali People of Kenya," Journal of African History 56, 3 (2015): 409-28.

13 Jeffrey Herbst, States and Power in Africa: Comparative Lessons in Authority and Control (Princeton, 2000), 251-52.

14 For further discussion on the concept of "wealth in people" as a specific mode of African accumulation and its different meanings, see Jane Guyer, "Wealth in People, Wealth in ThingsIntroduction," Journal of African History 36 (1995): 83-90. However, it would also be inaccurate to think that population counting began with colonialism. The rulers of the Asante kingdom undertook some forms of enumeration to assist in military planning, as reported by nineteenth-century traveler T. Edward Bowdich, Mission from Cape Coast Castle to Ashantee, 3d ed. (London, 1966 [1819]), 300. It has been suggested that these enumerations might have also been used for taxation purposes, Ivor Wilks, Asante in the Nineteenth Century: The Structure and Evolution of a Political Order (Cambridge, 1975), 80. Although this was not the case in Ghana, sometimes colonial statistics could be shaped by precolonial enumeration models and practices, as shown with reference to the Indian context by Norbert Peabody, "Cents, Sense, Census: Human Inventories in Late
} 
It is significant that in his census speech Nkrumah declared, "We shall surprise the world in the number and quality of our people and in the wealth of human resources at our disposal for building the nation." 15 This is consistent with Herbst's claim that, following independence, African politicians used nationalism as a tool to deal with the structural obstacles that had constrained state capacity in precolonial and colonial times. ${ }^{16}$ With reference to the specificities of postcolonial politics, this article follows in the footsteps of Jean-François Bayart. ${ }^{17}$ While his approach is firmly grounded in the longue durée, Bayart invited scholars to "de-exoticize" postcolonial African politics by critically engaging with the ways in which local actors absorbed, re-appropriated, and reinvented concepts, technologies of power, and modes of accumulation. Approached in this way, the importance of studying census propaganda lies in its capacity to illuminate the multiple connections between population counting and political imagination at a time characterized by a fervent hybridization of visions and practices that were brought together under the rubric of "development."

The starting point of my analysis differs from that of most discussions of census and state-building in Africa. Rather than understanding the political repercussions of population counting in terms of ethnic categorization, ${ }^{18} \mathrm{I}$ am interested in conceptualizing the relationship between the census and the building of the nation-state as mediated by the creation of public trust. ${ }^{19}$ Theodore Porter argued that the expansion of quantification as a social and political technology since the nineteenth century should be understood as a response to an increasing distrust toward non-standardized forms of expertise. ${ }^{20}$ In the public sphere, numbers were thought of as "objective" because quantification appeared to be a "technology of distance," capable of "escaping the bounds of place and culture." 21 Trust plays an even more crucial role in the collection of the raw data on which official figures are based: as noted by Harro Maas and

Precolonial and Early Colonial India," Comparative Studies in Society and History 43, 4 (2001): $819-50$.

15 Nkrumah, "Census Night," 43, my emphasis.

16 Herbst, States and Power, 126-30.

17 Jean-François Bayart, The State in Africa: The Politics of the Belly (London, 1996).

18 About Rwanda and Burundi, Uvin noted that there are "few countries where social constructivist expectations regarding identity and category seem to be so well verified"; "On Counting," 148.

19 My understanding of the politics of statistics as involving much more than quantification and classification has been largely inspired by Tong Lam, A Passion for Facts: Social Surveys and the Construction of the Chinese Nation-State, 1900-1949 (Berkeley, 2011); and Kathrin Levitan, A Cultural History of the British Census: Envisioning the Multitude in the Nineteenth Century (Basingstoke, 2014).

${ }^{20}$ Theodore M. Porter, Trust in Numbers: The Pursuit of Objectivity in Science and Public Life (Princeton, 1995).

21 Ibid., 9. 
Mary Morgan, one of the main differences between the numbers used in the natural sciences and economic and social statistics is that the latter "are always the outcome of a politically loaded interaction" between a subject who is counting and a subject who is being counted. ${ }^{22}$ While the recent historiography on statistics emphasizes the importance of taking into account resistance to counting in order to produce a more accurate view of human agency, ${ }^{23}$ attempts made by states to gain respondents' cooperation have, with a few exceptions, escaped systematic scrutiny. ${ }^{24} \mathrm{My}$ focus is precisely on those activities, institutions, and practices that, preceding the count, were aimed at gaining the trust of the people and explaining to them the importance of being counted. In Ghana, these attempts found expression in an extensive "Census Education and Enlightenment Campaign" conducted in schools and in the press. A focus on census education reveals the limits of understanding the link between statistics and state building as a story that is confined to the statistical office and other "centers of calculation." 25 To grasp the connection between statistics and the iconography of postcolonial state-building we must go beyond the statistical machinery and treat census-taking as part of a wider range of political iconographies disseminated by other key institutions of nation-making such as schools and the press.

The political iconographies constructed by the Census Education and Enlightenment Campaign were heavily mediated by the ideas and practices associated with "development," providing simultaneously an agenda for statebuilding and a shared language between international organizations and the first generation of African postcolonial policy-makers. ${ }^{26} \mathrm{~A}$ focus on census

${ }^{22}$ Harro Maas and Mary Morgan, "Observation and Observing in Economics," in Harro Maas and Mary Morgan, eds., Observing the Economy: Historical Perspectives, annual supplement to History of Political Economy 44 (Durham, 2014), 1-24, 15.

${ }^{23}$ Simon Szreter and Keith Breckenridge, "Editors' Introduction: Recognition and Registration: The Infrastructure of Personhood in World History," in Keith Breckenridge and Simon Szreter, eds., Registration and Recognition: Documenting the Person in World History (Oxford, 2012), 1-38, 12.

${ }^{24}$ Remarkable exceptions include Levitan, Cultural History; and Lam, Passion for Facts. Specifically on census publicity, see Margo Anderson, "Presidential Address: The Census, Audiences and Publics," Social Science History 32, 1 (2008): 1-18. On the other hand, census communication could also subvert the unity of the "imagined communities," and institutionalize prejudices about specific sections of the population. On representations of foreigners and lower classes as more likely to resist enumeration, see Paul Schor, "The View from Below and The View from Above: What U.S. Census-Taking Reveals about Social Representations in the Era of Jim Crow and Immigration Restrictions," in Heinrich Hartmann and Corinna Unger, eds., A World of Populations: Transnational Perspectives on Demography in the Twentieth Century (New York, NY, 1994), 19-35, 27-31. On the use of schools for census education and its implications, see Vicente Berdayes, "Official Statistics as Curriculum: Biopolitics and United States Census in Schools Program," Review of Education, Pedagogy and Cultural Studies 30, 2 (2008): 85-114.

${ }_{25}$ Bruno Latour, Science in Action: How to Follow Scientists and Engineers through Society (Cambridge, Mass., 1987).

26 On the "developmental" commitment of 1960s African states, see also Thandika Mkandawire, "Rethinking about Developmental States in Africa," Cambridge Journal of Economics 25, 3 (2001): 289-314. 
education allows a partial reassessment of the place of statistics within what James Ferguson called "development discourse," as well as a more refined understanding of the political implications of the reception of the "global" statistical standards disseminated by international organizations. ${ }^{27}$ In his classic study of Lesotho, Ferguson argued that what characterizes "development discourse" is its capacity to produce political effects (typically the extension of bureaucratic power) by depoliticizing the process of development. ${ }^{28}$ Within this framework, an important part of the "depoliticizing" nature of development follows from the embracement of a technocratic platform, which reimagines policies as being entirely based on the "objective" judgement of apolitical experts. The discourse disseminated by the "development apparatus" acts as an "anti-politics" machine through its capacity to mask the connection between "development" and concrete power relations and power structures. Although the construction of demographic statistics seems to fit comfortably in this model, I argue that the census education campaign prevented the count from being framed exclusively in the technocratic language of "development discourse." Complementing Ferguson's characterization of development as an "anti-politics machine," I show that the possibility of obtaining people's trust, without which an accurate census would have been impossible, was intimately linked with the "re-politicization" of the census in the form of a wide range of imaginative representations about the postcolonial state, Ghana's history, and its political leadership.

Yet, in order to understand the concrete ways in which these representations entered Ghana's political imagination, we need to go beyond the nationstate-however defined - as our field of investigation. In the postwar world, the rise of "global population" as a key object of development policy was intimately connected with new forms of knowledge and governance institutionalized by the United Nations, which emerged as a powerful center for the global dissemination of statistical standards. ${ }^{29}$ While in 1950 , when the United Nations inaugurated the first World Population Census Programme, the "population problem" was mostly seen as a Japanese, Indian, and Chinese affair, ${ }^{30}$

\footnotetext{
27 Daniel Speich, "The Use of Global Abstractions: National Income Accounting in the Period of Imperial Decline," Journal of Global History 6, 1 (2011): 7-28. On the postcolonial era, see Jerven, Poor Numbers.

28 James Ferguson, The Anti-Politics Machine: "Development," Depoliticization and Bureaucratic Power in Lesotho (Minneapolis, 1994).

29 Matthew Connelly, Fatal Misconception: The Struggle to Control World Population (Cambridge, Mass., 2008); Michael Ward, Quantifying the World: UN Ideas and Statistics (Bloomington, 2004), 3. For the context I am describing, the most important examples of United Nations directives in the field of census methods include United Nations, Handbook of Population Census Methods, 3 vols. (New York, 1958); and Statistical Office of the United Nations, Principles and Recommendations for National Population Censuses (New York, 1958).

30 Connelly, Fatal Misconception, ch. 4.
} 
by 1960 Africa had fully entered the global neo-Malthusian imagination. ${ }^{31}$ Among the twenty-four African countries that held population censuses between 1955 and $1962,{ }^{32}$ Ghana was the first independent country in Africa, south of the Sahara, to undertake a census explicitly designed to be part of the 1960 World Census Programme. ${ }^{33}$ Benjamin Gil, United Nations census expert and director of the social and demographic section of the Central Bureau of Statistics of Israel, travelled to Accra to turn the 1960 Population Census of Ghana into what he emphatically called the "first modern census of contemporary Africa." 34 For the Statistical Office of the United Nations, the essential features of a "modern" census included government sponsorship, defined territory, universality, simultaneity, individual units of enumeration, compilation, and publication. ${ }^{35}$ Furthermore, a "modern census" required the organization of a "census publicity campaign" that aimed to dissipate "any anxiety about regarding the purposes of the census," explain "the reason for various questions on the questionnaire," and provide "some guidance as to the manner in which these questions should be answered." 36 The recommendation that census education "should therefore be considered an important phase of census work and should not be unduly restricted for reasons of economy if the best possible census results are desired" clearly shows the importance the United Nations attached to the creation of public trust as a precondition for obtaining accurate population figures. ${ }^{37}$ Although in recent years

31 Marc Frey, "Neo-Malthusianism and Development: Shifting Interpretations of a Contested Paradigm," Journal of Global History 6, 1 (2011): 75-97, 85.

32 These were either total enumerations or sample surveys. United Nations, Economic Commission for Africa, Methods and Problems of African Population Censuses and Surveys 1955-1962 (Addis Ababa, 1963), 18. This should be understood as part of a global interest in the collection of demographic information: between 1955 and 1962 almost two hundred countries conducted a population census, Statistical Office of the United Nations, Demographic Yearbook 1962, Special Topic: Population Census Statistics (New York, 1962), 1.

33 Indeed, the only postcolonial African states that had conducted population censuses according to United Nations directives were in North Africa. The first postcolonial census of Sudan (19551956) preceded the Ghanaian one, but was not based on a total enumeration of the population. Many other censuses that attempted to conform to United Nations directives would follow the Ghanaian one by months; quite a few of them took place in December 1960. Finally, other censuses that had many of the features listed by the United Nations were held in countries that were still under colonial rule, like Uganda in 1959. For a synoptic view of African censuses between 1955 and 1962, and their coverage, see United Nations, Economic Commission for Africa, Methods and Problems, 10-16.

34 Benjamin Gil, "Demographic Statistics in Ghana," Paper presented to the seminar on African Demography, Paris, 20-26 Aug. 1959, Appendix B, 16.

35 Statistical Office of the United Nations, Principles and Recommendations, 3. Furthermore, Gil stressed that in order to be "modern" the Ghanaian census should have included a postenumeration survey; "Technical Aspects of the 1960 Population Census of Ghana," paper read at the first meeting of the Central Census Committee on 8 July 1959, by Dr. Benjamin Gil, United Nations population census expert) (hereafter "Technical Aspects"), 1-2, Public Records Archives and Administration Department, Accra (hereafter PRAAD), RG 3/5/1815/43-44.

36 Quoted in United Nations, Handbook, vol. 1, General Aspects of a Population Census, 84.

37 Ibid. 
much attention has been paid to the evolution of the United Nations, ${ }^{38}$ the focus has been on the construction of development ideas and statistical templates in the organization's headquarters rather than the implications of their reception in the developing world. The present article argues that census publicity, which has been largely overlooked, constitutes a valuable entry point for observing how the norms and standards produced by the "development apparatus" acquire new meanings in the political life of the recipient nations.

\section{BUILDING TRUST AT THE GRASSROOTS: THE SCHOOL EDUCATION}

\section{A M PAIG N}

The Gold Coast (as Ghana was called under colonial rule) held its first population count in 1891, shortly after the British occupied the country's southern coastal areas in 1874, establishing the Gold Coast Colony. Between 1891 and independence in 1957, census-taking became a standard feature of the colonial administration, taking place in 1901, 1911, 1921, 1931, and 1948. While the different geographical coverages of these counts closely mirrored the changing boundaries of British rule in the area, ${ }^{39}$ all these censuses were characterized by low reliability and serious undercounting. ${ }^{40}$ Faced with a lack of infrastructures, funding, and trained personnel, the colonial state typically possessed neither the commitment nor the capacity necessary to accurately count the people under its jurisdiction. ${ }^{41}$ This was not only a Ghanaian story, nor was it limited to the early decades of colonial domination. Still in 1951, the delegates of the Conference of Statisticians of Countries South of the Sahara agreed that a harsh climate, the necessity to cover vast areas with few roads,

38 On the United Nations and global governance, see Mark Mazower, No Enchanted Palace: The End of Empire and the Ideological Origins of the United Nations (Princeton and Oxford, 2009); Mark Mazower, Governing the World: The History of an Idea (London, 2012). On the United Nations' contribution to development thinking, see John Toye and Richard Toye, The UN and Global Political Economy: Trade, Finance and Development (Bloomington, 2004) and Richard Jolly, Louis Emmerij, and Thomas G. Weiss, UN Ideas that Changed the World (Bloomington, 2009), esp. chs. 5-7. More importantly for our discussion, see Ward, Quantifying the World.

39 The 1891 count referred only to "The Colony" (roughly, today's Accra, Western, and Eastern regions). In 1901 Ashanti and the Northern Regions were also included, while following Germany's loss of her African colonies in the First World War, Togoland was placed under the British administration and included in the 1921 census. What was then called British Togoland is today's Ghana's Volta Region.

${ }^{40}$ For a more technical discussion of the validity of different counts, see the classic R. Kuczsinky book, Demographic Survey of the British Empire, Volume I, West Africa (London, 1948), 389-446; J. C. De Graft-Johnson, "The Population of Ghana 1846-1967: A Digest and Discussion of the Data in the Official Counts and Censuses," Transactions of the Historical Society of Ghana 10 (1969): 1-12; E.V.T. Engman, Population of Ghana 1850-1960 (Accra, 1986), 55-116.

41 Ewout Frankema and Morten Jerven, "Writing History Backwards or Sideways: Towards a Consensus on African Population, 1850-2000," in Gareth Austin and Stephen Broadberry, eds., "The Renaissance of African Economic History," special issue of Economic History Review 67, 4 (2014): 907-31, 911. For a nuanced analysis of the relationship between census-taking, taxation, resistance, and state legitimacy in a different colonial context, see David W. Akin, Colonialism, Maasina Rule, and the Origins of Malaitan Kastom (Honolulu, 2013). 
and the high mobility and widespread illiteracy of African populations all severely impeded gathering reliable population returns. ${ }^{42}$

Another obstacle mentioned was that Africans were suspicious of census-taking. ${ }^{43}$ Indeed, historically, Ghana's population figures have been consistently shaped by people's distrust of the state. Occasionally, people's unwillingness to cooperate was attributed to "ignorance, fear, and stupidity," 44 but well into the 1950s it was explained as being due to "African cultural taboos" and fear of taxation. ${ }^{45}$ Beliefs that disclosing the number of one's children would bring bad luck might explain some of the under-enumeration in colonial counts. ${ }^{46}$ Fear of taxation was also firmly grounded in Ghana's history. Taxation was used to estimate the number of people living in a given area before the formal establishment of the Gold Coast colony, and can be traced back to the passing of the 1852 Poll Tax Ordinance. ${ }^{47}$ In 1884 , after the original ordinance had been repealed, the yearly Blue Book still claimed that "no means exist whereby a census could be taken of the Gold Coast settlements, the natives of which are suspicious of their numbers being counted, having, perhaps a lively recollection of the old days when the poll tax was in force." 48

Since the first census in 1891, people's distrust elicited different forms of resistance. One was plain hostility: for example, the 1948 census reported that in the southern part of the country a "source of error arose from the deliberate opposition and refusal to allow a count by a group of villages." 49 In other instances people fled the census takers. The District Commissioner of the Eastern Province during the 1911 census reported, "The Enumerators experienced considerable trouble, that there was a universal fear of a hut tax, and that in some cases on the approach of the Enumerator villages were deserted."50 In 1921, "some of the Chiefs and the people thought the Census a preliminary to the imposition of the Poll Tax," while "some fishermen at Chama" took to the sea to avoid being counted. ${ }^{51}$ Although in 1921 the overall attitude of the people toward the census seemed more favorable than in 1911, the report admitted that "even so, the conditions existing in the Gold Coast to-day

42 "Conference of Statisticians of Countries South of the Sahara (Draft Report) Salisbury, Southern Rhodesia, 30th July-7th August 1951," 9, The National Archives, London, CO/852/1078/2.

${ }^{43}$ Ibid.

44 B. M. Read, "Report of the Census of the North-Western Province, 1911," 5, PRAAD ADM $56 / 1 / 96$.

${ }^{45}$ These arguments are concisely reviewed in J.R.H. Shaul, "Sampling Surveys in Central Africa," Journal of the American Statistical Association 47, 258 (1952): 239-54.

46 Engman, Population, 41.

47 Ibid., 49.

48 Quoted in ibid., 53.

49 The Gold Coast, Census of Population 1948 Report and Tables (London, 1950), 9.

${ }^{50}$ Gold Coast Colony, Census of the Population, 1911 (Accra, n.d.), 5.

${ }^{51}$ Census Report 1921 for the Gold Coast Colony, Ashanti, The Northern Territories and The Mandated Area of Togoland (Accra, 1923), 16. 
absolutely prohibit the collection of accurate and entirely reliable statistics of population." 52

Finally, the counted subjects could choose to provide inaccurate information. In most cases this resulted in under-enumeration: as already noted in the 1891 census "the Returns supplied by the Native Chiefs are all more or less influenced by [the] ... dread of taxation." ${ }^{, 53}$ The provision of false information was obviously difficult to detect, but when it was discovered it could occasionally result in comical situations, like that described by a provincial commissioner in 1910:

On one chief I found it was absolutely necessary to inflict a fine, for whilst he was assuring me that he was poor and had no Cattle his veracity was fated to suffer a rude and unexpected shock, for a thunder storm which had been threatening suddenly developed, and his cattle which he had hidden in the bush on our approach, became terrified at the voilence [sic] of the storm, suddenly stampeded from their place of concealment and rushing into the town, in no unmistakable manner demonstrated their presence before my eyes and their perfidious owner. ${ }^{54}$

Although it was expected that political independence would make citizens less distrustful of the government's purposes for counting them, in the eyes of the Central Census Committee "a passive attitude to the event, due to lack of understanding, could be equally detrimental." "55 The extent to which these fears were justified was confirmed by a pilot survey conducted between 25 May and 6 June 1959 in a small selection of localities. Despite the fact that the test was preceded by a series of broadcasts on Radio Ghana, and though several enumerators had established contact with local chiefs to inform the populace of the initiative, the test revealed that of the cases in which interviewers faced "obstacles in enumeration" 10 percent were due to respondents' reluctance to exchange information and 8.9 percent to a lack of census publicity. ${ }^{56}$

The Central Census Committee's systematic attempts to gain people's trust set the 1960 census radically apart from its colonial predecessors. The

52 Census Report 1921, 16.

53 Report on the Census of the Gold Coast Colony for the Year 1891, 9. A. W. Cardinall, Chief Census Officer in the 1931 count, pointed out that there were instances in which the chiefs had incentives to over-report the number of the people living under their jurisdiction. This was especially the case when population returns formed "the basis of representation in the Provincial Councils," provided "the numbers on which the issue of gun permits, etc., are based," or it was thought that "an exaggeration of the number of one's subjects adds glory and power to the monarch," A. W. Cardinall, The Gold Coast, 1931. A Review of Conditions in the Gold Coast in 1931 as Compared with those of 1921, Based on Figures and Facts Collected by the Chief Census Officer of 1931, together with a Historical, Ethnographical and Sociological Survey of the People of that Country (Accra, 1932), 123-24.

54 Colin Harding, Acting Provincial Commissioner of Wa Province to Acting Chief Commissioner, Tamale, 16 Jun. 1910, p. 3, PRAAD ADM 56/1/96.

55 Benjamin Gil and de K.T. de Graft-Johnson, The 1960 Population Census of Ghana, vol. V: General Report (Accra 1964), 153.

56 Census Office and Benjamin Gil, 1960 Population Census of Ghana: Report on the First Field Test (25th May-6th June 1959) (Accra, n.d.), 58. 
importance Gil attached to obtaining the cooperation of the public at largesomething he said was not yet receiving enough attention in African censuses $^{57}$ - had far-reaching implications for the choice and training of enumerators, the activities taking place in the field, and the new institutional infrastructure charged with educating the public. The Census Education and Enlightenment Campaign brought together statistical experts, administrative bodies, and government departments that dealt with information and mass education. ${ }^{58}$ By December 1959, the campaign's activities included the printing of eight thousand posters translated into the main vernacular languages, the publication of a few thousand copies of a booklet titled Knowing Ourselves, regular broadcasts on Radio Ghana, publicizing in newspapers, and the production of a ten minute movie. ${ }^{59}$ The movie, significantly titled Answer for Tomorrow, was screened in urban cinemas and projected in rural areas with the vehicles of the Social Welfare Department. It showed "a mother feeding five hungry children," "children having to walk several miles to school every day," "a family in search of accommodation," and overcrowded medical facilities, thereby pointing at pressing social problems-regarding nutrition, health, education, and housing - that the census could help to solve. ${ }^{60}$

According to Gil, only simultaneous actions on all of these fronts would achieve the campaign's main goals, which included, but were not limited to, "Issue of information for the literate public," "Creation of enthusiasm among the thousands of potential enumerators," and "Stimulation of devotion on the part of the Census staff." ${ }^{\prime \prime}$ The 1960 census employed some seven thousand enumerators and was undoubtedly the largest and most labor-intensive statistical inquiry ever conducted in Ghana to that point. Ensuring not only the competence but also the enthusiasm and commitment of the census staff became crucial. Census officers had to be persuaded that they were taking part in a great national enterprise. "By your selection for appointment," the Minister for Economic Affairs told the first cohort of regional census assistants and

\footnotetext{
57 Gil, “Technical Aspects," 1, PRAAD RG 3/5/1815/43; Gil, "Demographic Statistics in Ghana," 7.

58 "Meeting of the Census Education Committee on August 7, 1959, at Census Head Office," 1, PRAAD RG 3/5/1815/57.

59 Meeting of the Central Census Education Committee on December 221959 at the Census Head Office at 2.30 p.m., pp. 1-3, PRAAD RG 3/5/1816/218-220.

${ }^{60}$ Unfortunately I have been unable to find a copy of the movie. This account is based on the description of the movie in Gil and de Graft-Johnson, Census, vol. V, 157. For further discussion on the use of movies as educational material in Anglophone Africa, see Rosaleen Smyth, "Film as Instrument of Modernization and Social Change in Africa," in Peter J. Bloom, Stephan M. Miescher, and Takyiwaa Manuh, eds., Modernization as Spectacle in Africa (Bloomington, 2014), 65-88. On representations of poverty in colonial movies about Ghana, see Gareth Austin, "Poverty and Development as Themes in British Films on the Gold Coast, 1927-1957," in Lee Grievison and Colin MacCabe, eds., Film and the End of Empire (Basingstoke, 2011), 225-35.

61 Gil, "Demographic Statistics in Ghana," Appendix B, 15.
} 
census district officers, "you are therefore entitled to consider yourself fortunate and to be justly proud of the National privilege conferred upon you."62

The connection between schools and census-taking did not begin in 1959: school teachers and school masters had already been widely employed as enumerators in the colonial censuses of 1921,1931 , and $1948 .^{63}$ Their suitability to act as enumerators had been justified on the ground that they were unequivocally literate and employed in the public sector. ${ }^{64}$ It was also argued that they more likely to be perceived as detached from tax collection, which as we have seen was a recurrent source of misunderstanding facing colonial census-takers. In colonial counts, the process of acquiring the trust of the counted subjects strictly followed a vertical, top-down approach: the administration tried to persuade the chiefs that the census was necessary and detached from taxation, and the chiefs in turn tried to convince the population to cooperate.

These practices continued in the 1960 census, with Gil travelling to different parts of the country to address the chiefs ${ }^{65}$ and reinforcing the message that the "school teacher is the person who will be favourably accepted by the population as he brings the benefit of education to the children" and "will not be associated with tax paying or any other administrative operations." "66 Gil also noted that the teachers were best qualified not only to estimate the age of the children when this was unknown, but also, through that, to infer the age of their parents. ${ }^{67}$ However, the radical novelty of Gil's approach was the idea that school teachers were ideally located to teach the pupils themselves the usefulness of the census. ${ }^{68}$ His notion that "the children will act as the best communication media; through the children we want the Census idea to reach the parents and enlighten them" 69 represented an important change in approach.

In order to transform the children into agents of "modernization from below," the Ministry of Education prepared a series of special lectures that

62 Press release no. 749/59, The National Archives, London DO 35/9231.

63 Yet still in 1960 in the Northern Territories, where there were not enough teachers, the task fell partly on agricultural officers. "Central Census Committee, Second Meeting held at the Prime Minister's Conference Room at 9 a.m. on 3rd December 1959," 3, PRAAD RG3/5/1816/239.

64 See also Benjamin Gil and Emanuel N. Omaboe, "Population Censuses and National Sample Surveys in Developing Countries," in Martin Bulmer and Donald P. Warwick, eds., Social Research in Developing Countries: Surveys and Censuses in the Third World (Chichester, 1983), 41-52, esp. 44-45.

65 See, for example, the picture depicting Gil talking with the Paramount Chief of Ho in Ghana Times, 26 Oct. 1959: 5. This was part of a much larger set of meetings and public events at which District Commissioners and Census officers addressed the chiefs. See for example "At the AllWomen's Rally: Census Will Assess Ghana’s Manpower,” Ghana Times, 23 Dec. 1959: 3.

66 Dr. Benjamin Gil, “The General Framework of Census Education” (Accra, 3 Aug. 1959), 2, PRAAD RG 3/5/1815/50.

67 Ibid.

68 Ibid.

69 Gil, "Technical Aspects," 3, PRAAD RG 3/5/1815/45. 
the teachers studied and then delivered in the classrooms of the schools targeted for the initiative. Unfortunately, out of the twelve lessons planned, to the best of my knowledge only the texts of the first three have survived in the archives, while the fourth is reprinted in the census' General Report. ${ }^{70}$ Luckily, from these lecture notes it is still possible to glimpse the representations of the state the campaign articulated and to get a sense of the discursive strategies it employed to mobilize Ghanaian youths to make the public "census minded.",71

But how did the campaign go about explaining the census to the children and convincing them of its importance? A recurring strategy was to compare census-taking to tasks faced by pupils and teachers in their daily lives. For example, in the first lesson enumerating people was compared to compiling class registers. ${ }^{72}$ More importantly, the census education campaign was designed to represent the state as a benevolent, inclusive, and knowledgeable entity:

You will be interested to know that with respect to teachers the Ministry of Education knows the number - here are the figures.... Is this not interesting? How many children are in approved primary and middle school? Again the Ministry knows the figure to a child....

This year there are 465,290 children in approved primary schools and 139,984 in approved middle schools - making a total of 605,274 children. The boy or girl sitting in the corner of the classroom and the child in the 2 nd column, 4 th row in the class are included in the total. I think each school child should be proud to know that the Ministry of Education regards or sees him or her as an individual. ${ }^{73}$

The second lesson, titled "Census as a Form of Measurement," claimed that the government, despite its extensive knowledge, had "no money but that which belongs to the people," and thus was burdened with the moral responsibility of spending it in the wisest possible way to everyone's benefit. ${ }^{74}$ This passage tackled the fears that census-taking would result in increased taxation: far from being aimed at acquiring additional resources, the census was simply a necessary tool to allow the government to spend people's money (presumably already collected) in the best possible way. Furthermore, the second lesson put across the message, again illustrated with a variety of everyday examples, that "the idea of measurement, whether applied to space, time, weight, distance, or

${ }^{70}$ Gil and de Graft-Johnson, Census, vol. V, 167-68.

71 This is an expression that recurs in minutes of the Census Education Committee and in other writings related to the educational activities. See, for instance, Ministry of Education, 27th Oct. 1959, "Population Census - Ghana 1960: Census Education and Enlightenment Campaign: Special Letter to Field Assistant Education Officers," 3, PRAAD RG 3/5/1816/212.

72 Ministry of Education, 28 Oct. 1959, “Ghana’s 1960 Population Census, Census Education, Reasons for Holding the Census, Lesson I,” 1, PRAAD RG 3/5/1816/199.

73 Ibid., 4, PRAAD RG 3/5/1816/202.

74 Ministry of Education, 29 Oct. 1959, “Ghana 1960 Population Census, Census Education, Lesson II, Subject: Man and Measurement: Census as a Form of Measurement," 3, PRAAD RG $3 / 5 / 1816 / 206$. 
area is indispensable if men have to live wisely, and that measurement is in fact photographed on every aspect of civilized life." ${ }^{75}$ This message echoed the iconography of mathematics textbooks produced in the last years of colonial rule. Like the census campaign, the 1954 middle school textbook $A$ West African Mathematics presented measurement and quantification as preconditions for economic and social advancement: "Mathematics help us to work out how to make the things we need in modern life. Without Mathematics, there would be no shops, no motor cars, no railways, no bulldozers to clear the forests, no electric light, and we should probably have to live forever in caves or very simple huts."76 The education campaign differed from the textbook by placing the state at the center of its narrative of measurement and progress.

The third lesson, "Everyone Shall Count as One Person, Not More Not Less" built on the arithmetic problem. The Ministry of Education stated that if the single task of counting each individual (compared to the different steps of the problem) was flawed because of lack of cooperation with the enumerators, the final result would be wrong: "If you will say 'I do not matter' and that fellow 'he does not matter' the correct population of Ghana will not be known. $" \overline{77}$ Besides reiterating the image of the state as an inclusive and benevolent agent capable of complicated acts of calculation, the lecture introduced the key theme of the interdependence between individual conduct and the overall result of the census. ${ }^{78}$ By reflecting on the "individual" as both a unit of enumeration and as an agent of political transformation we can fully understand the reception of the United Nations template and its unintended consequences. Indeed, in the rhetoric institutionalized by the United Nations, population censuses embodied a democratic (and egalitarian) attitude; it stressed that the "importance of the population count is that each person represents an individual "vote," regardless of gender, income, location, or social status. ${ }^{79}$ This stance was reflected in the United Nations' emphasis on the crucial importance of adopting a single template for the whole population, and of choosing the individual as the unit of recording and enumeration. ${ }^{80}$ The incorporation of these features represented a significant departure from previous statistical methods applied in Ghana, ${ }^{81}$ and they became markers of

75 Ibid., 2, PRAAD RG 3/5/1816/205.

76 G. R. Gibson and T. J. Mardell, A West African Mathematics, 3 vols. (London, 1954), book 1,11 .

77 Ministry of Education, 30th Oct. 1959, "Census Education, Everyone Shall Count as One Person not More nor Less," 2, PRAAD RG 3/5/1816/209.

78 The narratives of the Ghanaian education campaign share striking similarities with the more recent experience of the Census in School program in the United States analysed in Berdayes, "Official Statistics."

${ }_{79}$ Ward, Quantifying the World, 189.

${ }^{80}$ United Nations, Handbook, vol. 1, 5.

81 Individual enumeration had been attempted in the 1911, 1921, 1931, and 1948 counts, but was limited to the urban areas, while all colonial counts were characterized by the employment of 
the 1960 census' "modernity." The combination of individual enumeration on a separate line, and the choice of a single form for the entire population, not only extended the scope for statistical analysis, ${ }^{82}$ but also evoked the possibility of building a postcolonial nation-state made up of equal citizens. ${ }^{83}$ Following this logic, in the United Nations' rhetoric, census publicity could be seen as promoting the importance of being counted as individuals who were effective political participants.

These lessons were delivered via a broad range of activities targeting local communities, with children marching with placards to raise awareness of the census (figure 1). Field assistant education officers were sent on ten-day visits to villages to establish contacts with the chiefs and distribute the campaign material to the teachers, while head teachers were asked to maintain a separate exercise book titled "The 1960 Census" in which they noted all work done as part of the education campaign. ${ }^{84}$

The census education campaign sat at the intersection of colonial strategies and new forms of state intervention. The widespread use of radio, cinema, and newspapers in mass education campaigns had already emerged in the 1940s and found expression in fields like extramural education, agriculture, and health. ${ }^{85}$ In the early 1950s the Convention People's Party had become aware of mass education's importance for mobilizing local communities and promoting civic virtues. ${ }^{86}$ But in the aftermath of independence the mobilization of the youth took on a new urgency; it became a pillar of postcolonial state-building and a crucial element in the socialist transformation envisaged by Nkrumah. ${ }^{87}$ The latter aspect reveals the fluidity of the political visions for which children were mobilized. The centrality of school pupils as agents of "modernization from below" in the 1959-60 census campaign shared similarities with the Young Pioneers movement established in 1960, though there were

different questionnaires for different sections of the population, typically with a census form for urban Africans, one for rural Africans, and one for non-Africans.

${ }_{82}^{82}$ Gil, "Technical Aspects," 1-2, PRAAD RG 3/5/1815/43-44.

${ }^{83}$ This was not an exclusive prerogative of censuses following the directives of the United Nations. See, for example, the discussion of the 1909-1911 census in Qing China in Lam, Passion for Facts, 17, 66.

${ }^{84}$ Ministry of Education, 27 Oct. 1959, "Population Census-Ghana 1960: Census Education and Enlightenment Campaign: Special Letter to Field Education Officers," 2-4, PRAAD RG 3/ 5/1816/211-213. See also Gil and de Graft-Johnson, Census, vol. V, 166-67.

${ }^{85}$ Smyth, "Film as Instrument of Modernization," 73; Peter J. Bloom, "Elocution, Englishness and Empire: Film and Radio in Late Colonial Ghana," in Peter J. Bloom, Stephan M. Miescher, and Takyiwaa Manuh, eds., Modernization as Spectacle in Africa (Bloomington, 2014), 136-55.

${ }^{86}$ Kate Skinner, "'It Brought some Kind of Neatness to Mankind': Mass Literacy, Community Development and Democracy in 1950s Asante," Africa: Journal of the International African Institute 79, 4 (2009): 479-99.

${ }^{87}$ For further discussion on this, see Jeffrey S. Ahlman, Living with Nkrumahism: Nation, State, and Pan-Africanism in Ghana (Athens, Oh., 2017), ch. 3. 


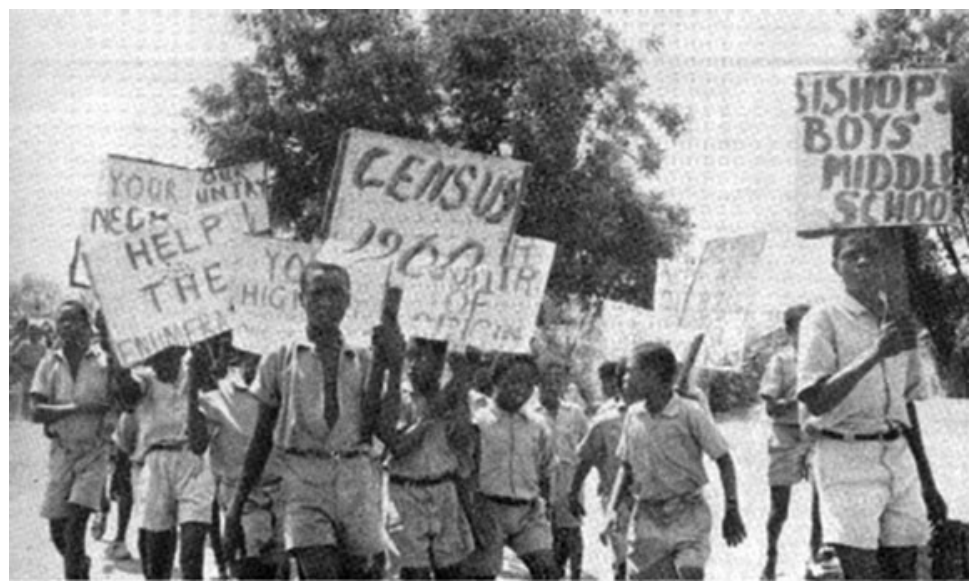

Figure 1. School children show their support for the census. Gil and de Graft-Johnson, Census, vol. V, n.p. Reproduced with permission of the Ghana Statistical Service.

many crucial differences. The Pioneers drew inspiration from their Soviet counterpart, and in the Ghanaian imagination they evoked dark tales of brainwashing and coercion. People saw them as spies who reported to the local authorities expressions of dissent against the regime, even those uttered by their parents. ${ }^{88}$ Furthermore, the content and language of the census campaign's educational materials was quite unlike the "Nkrumaist gospel" imposed on the Pioneers, which emphasized new forms of revolutionary citizenship, and loyalty to the Convention People's Party and to Nkrumah as the nation's messiah. ${ }^{89}$ Despite these differences, when we look at the campaign and the movement in the same historical frame, they appear as complementary elements of an emerging order in which children were employed to project, mediate, and disseminate new, official representations of the postcolonial state at grassroots levels. It would be overreaching to suggest that the census campaign directly shaped the evolution of the Young Pioneers, but it is ironic that some of the

${ }^{88}$ Ahlman, Living with Nkrumahism, ch. 3. For a defense of the movement against these accusations, see the account of one of the organization's early leaders, M. N. Tetteh, The Ghana Young Pioneer Movement: A Youth Organization in the Kwame Nkrumah Era (Accra, 1999). Ahlman shows that the situation was more complicated, with some evidence that the Young Pioneers did indeed act as spies, while he also claims that the anxiety surrounding the movement was rooted in a wider series of concerns reflective of the mismatch between the government's invasive children mobilization and their families' expectations; Living with Nkrumahism, 102-9.

89 The content of the indoctrination to which the Young Pioneers were subjected led to a conflict between church and state, resulting in the deportation of Richard Roseveare, Anglican Bishop of Accra, after he claimed that the Young Pioneers were confusing "the work and example of a great man [Nkrumah] with Divine Acts which are unique in history"; quoted in Bengdt Sundkler and George Steed, A History of the Church in Africa (Cambridge, 2004), 945. 
same children who were inviting their parents and their local communities to trust the state and become known to the government through the choice of being counted would become a central trope in the political culture of silence, fear, and suspicion that characterized Ghana's authoritarian evolution. $^{90}$

\section{THE CENSUS AND THE STATE IN THE PRESS}

Far from being limited to schools, discussions and events to make the public "census-minded" were set up by actors as different as members of the ruling party, leaders of the women and farmers' associations, and religious organizations. ${ }^{91}$ As part of the education campaign, the census also received widespread coverage in the press. Between October 1959 and March 1960 more than four hundreds articles, cartoons, and slogans reminded people of census night, invited them to trust the enumerators, and documented the progress of propaganda activities in different parts of the country. ${ }^{92}$ The census' General Report maintained that the press' most important contribution was to keep the inquiry "out of controversial matters" and present it "as a national and nonpartisan operation." ${ }^{93}$ However, the count took place when Ghana was about to embark on the plebiscite that would result in the adoption of a Republican Constitution. The Republican Constitution vested much greater executive power in Nkrumah's hands, allowing him to rule by decree and bypass the Parliament. ${ }^{94}$ The census report argued that by postponing the plebiscite the government showed awareness that a simultaneous occurrence of the two events would have undermined the image of the census as a non-political and non-partisan operation. ${ }^{95}$ Yet, in the daily papers we find evidence of the many ways in which the census was re-politicized in connection with the upcoming presidential election. Furthermore, given the extreme importance Nkrumah's government attached to the media as a tool of political education, and the increasingly repressive climate in which newspapers operated, textual and visual representations in the press inscribed population counting into broader narratives about the postcolonial state. ${ }^{96}$

90 On silence, fear, and political denunciation in Nkrumah's Ghana, see especially Jeffrey S. Ahlman, "Living with Nkrumahism: Nation, State and Pan-Africanism in Ghana," PhD thesis, University of Illinois at Urbana-Champaign, 2011, ch. 6.

91 “This Census Is Important-Says Appiah Danquah,” Evening News, 19 Mar. 1960: 5.

92 According to the general census report "there appeared 444 items (articles, news, reports, advertisements and separate photographs and drawings) covering 12,137 square inches of newspaper space," Gil and de Graft-Johnson, Census, vol. V, 155.

93 Ibid.

94 See especially The Constitution of the Republic of Ghana, part X, "Special Powers for First President," 55.2.

95 Gil and de Graft-Johnson, Census, vol. V, 159.

96 Jennifer Hasty, The Press and Political Culture in Ghana (Bloomington, 2005), 9-11. 
The Ashanti Pioneer explicitly sided in the presidential election with Nkrumah's opponent J. B. Danquah (who would eventually become the most famous victim of the Preventive Detention Act, dying in prison in 1965), and invited its readers to vote against the constitutional changes proposed by the government. References to the census were scant, and usually limited to small reminders of the census date, while much attention was devoted to raising awareness of the excessive concentration of power in Nkrumah's hands that would result from the approval of the Republican Constitution. ${ }^{97}$ The dissident voice of the Ashanti Pioneer would be silenced in February 1961 when the newspaper was placed under a government appointed censor. ${ }^{98}$ In contrast, the Ghana Times and the Daily Graphic, aligned with the ruling party, provided frequent updates about the progress of census activities. ${ }^{99}$ However, it was the Accrabased Evening News that hosted the most powerful and imaginative narratives about the count. This is not surprising given that the paper was established by Nkrumah himself in 1948, and was later described by him as "the vanguard of the movement and its chief propagandist, agitator, mobilizer and political educationalist." ${ }^{100}$ An interesting example of this process of reinvention comes from an article published on 19 March 1960 by Ghanaian Mabel Dove, a leading female commentator on socio-political affairs: ${ }^{101}$

The eve of Ghana's Freedom, that was a memorable night, a never-to-be forgotten night when the Leader Kwame Nkrumah recalled the agony of the struggle and tears ran down his checks $[s i c] \ldots$ the tears for past suffering and the tears of joy for freedom, that was 5th March 1957 when the church bells tolled and the great crowd in their thousands shouted Freedom Freedom!... March 6 has now gone down in history as the greatest day when Kwame Nkrumah made history ... and again in March, Sunday the 20th of March, bonfires will light up towns, villages and hamlets and the flames will shed a radiance all over the country whilst men, women and children rejoice and dance to the strains of the drums....

Remember the SECOND GREAT NIGHT OF GHANA AFTER INDEPENDENCE, CENSUS NIGHT-A NIGHT TO REMEMBER. ${ }^{102}$

Building on the coincidence that both the country's independence and census night occurred in March, the article did not simply treat census-taking as one

\footnotetext{
${ }^{97}$ For example, "Don’t Surrender Your Rights to Political Rascals—Says Public Eye," Ashanti Pioneer, 19 Mar. 1960: 2.

98 Austin, Politics in Ghana, 389.

99 There were, however, important differences between the two newspapers. While the Ghana Times was state-owned from its foundation in 1958, the Daily Graphic became a state paper only in 1962 after the government exerted increasing intimidation to control its content; Hasty, Press, 33-34.

${ }_{100}$ Quoted in Ansah, "Kwame Nkrumah and the Mass Media," 90.

101 Mabel Dove was also Danquah's former wife, but joined Nkrumah's party in 1951. The reasons behind this choice are explained in a 1951 article reprinted in Stephanie Newell and Audrey Gadzekpo, eds., Mabel Dove: Selected Writings of a Pioneer West African Feminist (Nottingham, 2004), 102-3.

${ }_{102}$ Mabel Dove, "Remember the Census Night of Ghana," Evening News, 19 Mar. 1960: 3.
} 
of the landmarks of postcolonial political sovereignty but, by turning census night into "the second great night of Ghana," it inscribed population counting in a national epic of political struggle and self-determination. The incorporation of the census into a national tale of sacrifice can also be observed in a picture depicting a vast cheering crowd above the inscription "We'll Live and Die for Ghana / We're Ready for the Census." 103

The pages of the Evening News also open a window into a feature that increasingly characterized Ghana's political life in the 1960s: the cult of Kwame Nkrumah. The employment of religious references had characterized Nkrumah's political persona since his rise to prominence in the years of decolonization, ${ }^{104}$ but in the early 1960 s this "political theology" became a pervasive feature of public discourse. The struggle for the construction of "Nkrumaism" as the new official ideology that could guide Ghana's socialist transformation was based on the combination of elements of nationalism and Pan-Africanism with echoes of Marxism-Leninism, often read through a religious and occasionally mystical iconography. This was particularly evident in the press, where Nkrumah was often referred to as the Osagyefo, literally "the redeemer," or "The Good Shepherd," or "Africa's Man of Destiny." 105 Public meetings sometimes "began with such songs as If you follow him [Nkrumah], he will make you fishers of men," with an obvious reference to the Gospel. ${ }^{106}$

In the Evening News, the census and the presidential election were explicitly connected, and both were instrumental in presenting Nkrumah as the savior of the nation:

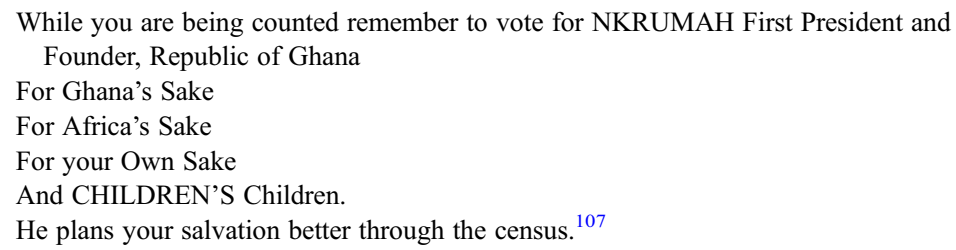

103 "All Set for Census Night the Prime Minister Broadcasts Tomorrow," Evening News, 19 Mar. 1960: 8 .

104 One of the slogans in the fight for independence was "Seek ye first the political kingdom, and all else shall be added onto you" (a reference to the gospel of Matthew, 6:33), but in his autobiography Nkrumah famously said "I am a non-denominational Christian and a Marxist socialist and I have not found any contradiction between the two"; Kwame Nkrumah, Ghana: The Autobiography of Kwame Nkrumah (London, 1971), 12.

${ }^{105}$ For further discussion on the religious underpinnings of Nkrumah's cult, see Ebenezer Obiri Addo, Kwame Nkrumah: A Case Study of Religion and Politics in Ghana (Lanham, 1997), esp. chs. 6,7 , and 8 .

${ }^{106}$ Omari, Kwame Nkrumah, 85.

107 The same strategy of using census rallies as part of Nkrumah's electoral campaign was employed by the Convention People's Party. "Census Day Draws Nigh: Rallies Increase," Evening News, 16 Mar. 1960: 5. 
As eloquently shown by Achille Mbembe with reference to Cameroon, newspaper cartoons can be useful tools to reconstruct the political culture of the "postcolony." 108 Indeed, a cartoon published in the Evening News on the 18 March 1960 reinforces the depiction of Nkrumah as the savior of the nation, and the census as the tool through which he could plan a better future for present and future generations, while simultaneously suggesting additional meanings (see figure 2). ${ }^{109}$

In an effort to avoid misunderstandings, the census schedules omitted questions about citizenship; these were replaced by questions about country of origin. Possibly unintentionally, the cartoon seems to represent "true" citizenship as following from the expression of loyalty to the government through the choice of being counted, rather than in connection with legal status. The choice to be counted is productive of new political identities: it makes people "true and free citizens of Ghana," and acts as a device of transfiguration, closing the gap between the people and the Leader. Indeed both the facial features and the cry of the child on the left leave no doubt that the joyful man at the center of the composition is Nkrumah himself. This illustration removes the census from the realm of the state as rational and bureaucratic agent and uses it to articulate the narrative of its mystical personification in the father of the nation. Carrying the Christian analogy to its extreme implications, the fish on the left hyperbolically suggests the participation of the natural world (presumably made possible by Nkrumah's Christic attributes) to the project of national construction reified in the census. Similarly, the man weeping for having chosen not to be counted, leading to his exclusion from the nation-state, evokes the suffering of those in hell who are excluded from the light of God. But, unlike hell, the postcolonial state offered an opportunity of redemption with the next census.

With the count finally approaching, the Evening News reported that the people of Ghana were caught up in what was emphatically called "census fever."110 At 6.10 p.m., Nkrumah gave a radio broadcast reminding the people that the "most important element ... is your co-operation," without which "the best plans and organization, and the efficiency of the field staff will not achieve the results we want."111 Across the whole country census night was celebrated with "traditional" drumming, dancing, candle processions,

108 Achille Mbembe, On the Postcolony (Berkeley, 2001), ch. 3.

109 Yaw Boakye Ghanatta, the author of the cartoon, produced some of the most hagiographic depictions of Nkrumah and his regime. After Nkrumah's toppling in 1966, he started portraying Nkrumah as inept, greedy, and incompetent; Baba G. Jallow, "From Saint to Devil: The Visual Transformations of Kwame Nkrumah in Accra Evening News Cartoons, 1961-1966," Stichproben: Wiener Zeitschrift für kritische Afrikastudien / Vienna Journal of African Studies 27, 4 (2014): $79-103$.

110 "It's in the Air! Census Fever," Evening News, 14 Mar. 1960: 1.

111 Nkrumah, "Census Night," 43. 


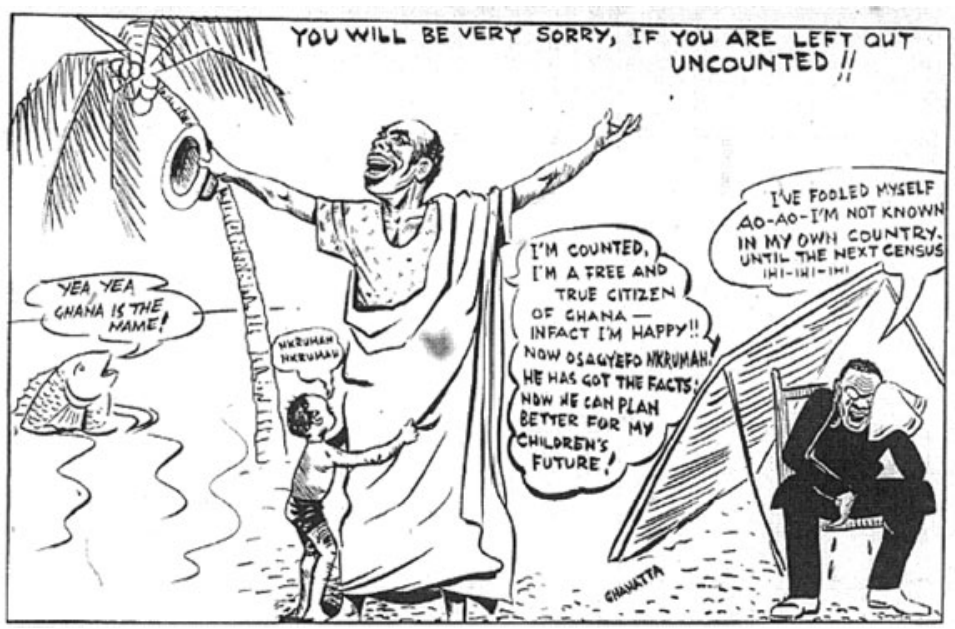

Figure 2. Ghanatta, "You will be very sorry, if you are left uncounted!!" Evening News, 18 Mar. 1960.

football matches, bonfires, tolling of church bells, mass religious services, and beating of drums. The 20th March celebrations served both symbolic and practical purposes. Since the 1960 count was a de facto census - counting the people actually present in the country during the enumeration rather than the usual residents (a de jure census) - the festivities could "impress on the whole population this specific date which was used as a reference date for several census items" and, by enumerating each individual "only at the place of stay of Census night" reduce the potential for ambiguous answers, confusion, and double counting. ${ }^{112}$ On the other hand, by inscribing the census into the nation's memory and subjugating the national population "to a social time fixed by the government," $" 113$ the festivities articulated the vision of an "imagined community" in which spatial differences lost meaning, and in which the notion of the census as a secular, rationalistic, and technocratic exercise was complemented with narratives of "traditional" culture (see figure 3).

THE CENSUS RESULTS

After the bonfires were extinguished, the drum beating stopped, and the dancing ceased, the enumeration began at 6 a.m. on 21 March. ${ }^{114}$ In vestiges of the colonial order and in new architectural sites celebrating the power of Nkrumah's regime, in urban shanty towns and coastal villages, in the northern

\footnotetext{
112 Gil and de Graft-Johnson, Census, vol. V, 158.

113 Lam, Passion for Facts, 121.

114 Gil and de Graft-Johnson, Census, vol. V, 193.
} 


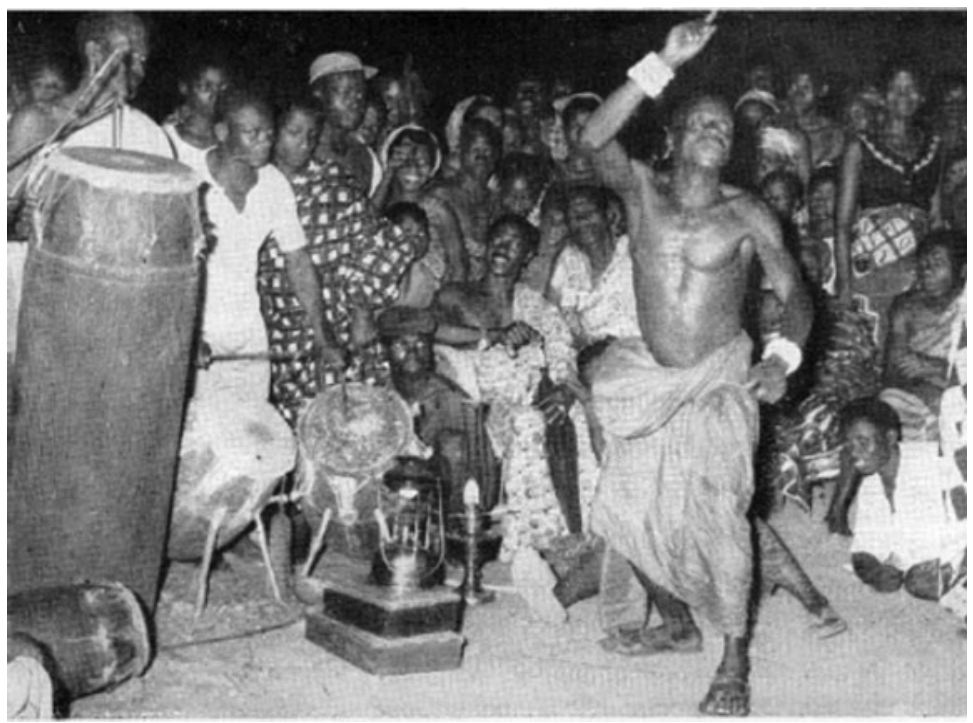

FiguRE 3. "A typical village observed "Census night" with drumming. A dancer invokes the help of the spirits to ensure a successful census." Gil and de Graft-Johnson, Census, vol. V, n.p. Reproduced with permission of the Ghana Statistical Service.

savannah and in the forest belt, questions were asked and questionnaires were filled. The census forms were then gathered and processed in the headquarters of the statistical office in Accra with newly purchased IBM electronic punchcard machines. ${ }^{115}$ The provisional results of the count were released in May 1960: the total population of Ghana amounted to $6,690,730 .^{116}$ The final population figure, published the following December, was even higher, amounting to $6,726,815 .^{117}$ This largely exceeded the United Nations 1958 projections (based on 1948 figures) that had estimated the population in 1960 would be 4,980 million, and reach 6,100 million only in $1975 .^{118}$ The difference between the total population recorded in 1960 and 1948 figures was around 2,600,000 people. Since this implied an implausible population growth of more than 60 percent in just twelve years, it seemed evident that underenumeration in the last colonial count was larger than previously thought. Of course, it was also possible that some of this discrepancy was due to

115 These phases are described in considerable detail in Gil and de Graft-Johnson, Census, vol. V, chs. 14-18.

116 Provisional results of the 1960 Population Census of Ghana, attachment to Press Release no. 387/60, The National Archives, London, DO 35/9281. Additional details on the tabulation and publication of the figures can be found in the folder PRAAD RG3/5/1817.

117 Ghana Census Planning Office, Census, vol. I, xiii.

118 United Nations Department of Economic and Social Affairs, The Future Growth of World Population (New York, 1958), Appendix C, Table II, 72. 
over-enumeration in the 1960 count, as voiced by "certain foreign circles" in the immediate aftermath of the figures' publication. ${ }^{119}$ But these fears were largely dispelled by the post-enumeration survey. ${ }^{120}$ In any case, such a high population figure qualified the pro-natalist orientation that characterized the early years of Nkrumah's rule. ${ }^{121}$ In 1964, the Seven-Year Plan for National Reconstruction and Development, an ambitious blueprint that should have directed the transformation of Ghana into an industrialized socialist economy, claimed that a "growing population presents an opportunity as much as a problem."122

Outside Ghana, the census was greeted as an example of good statistical practice from which other African countries could learn. The heads of other African statistical offices were invited on a study tour to observe the implementation of the post-enumeration survey. ${ }^{123}$ In 1961 the Ghanaian government, in cooperation with the United Nations Economic Commission for Africa, set up and hosted a West African Training Centre in Population Census Techniques. $^{124}$ Although in some respects some of the data produced by the census compared unfavorably with that produced by other African countries, the 1960 count stood as a landmark. ${ }^{125}$ Still in 2005 , the Ghana Statistical

119 “1960 Census: The Highlights of Ghana's Record Increase in Population...," Evening News, 18 Dec. 1962: 5.

120 Not only did the post-enumeration survey show that the 1960 census included a slight underenumeration, but it also pointed out, somehow counterintuitively, that the main enumeration was more accurate than the post-enumeration survey itself; Engman, Population, 113.

121 Pro-natalist attitudes were not exclusive to the political rulers. In a survey conducted among the Ghanaian urban elites at the time of the dissemination of census results, a large majority of the people interviewed hoped that the Ghanaian population would continue to grow rapidly in the future. Although it was initially suspected that these positions were in some cases the consequence of the effectiveness of the government's propaganda, or fear of expressing lack of confidence in the regime, the interviewers became convinced of the overall sincerity of the answers. John C. Caldwell, Population Growth and Family Change in Africa: The New Urban Elite in Ghana (Canberra, 1968), 42-43.

122 Ghana, Office of the Planning Commission, Seven-Year Plan for National Reconstruction and Development, Financial Years 1963/64-1969/70, Approved by Parliament on 16th March 1964 (Accra, 1964), 8. Nkrumah's pro-natalist attitude was completely reversed in the aftermath of his toppling, when the new military government committed to the implementation of family planning programs to reduce population growth. Following in the footsteps of Kenya, Ghana was the second country in Sub-Saharan Africa to do so. John Caldwell and Fred T. Sai, "Family Planning in Ghana," in Warren C. Robinson and John A. Ross, eds., The Global Family Planning Revolution: Three Decades of Population Policies and Programs (Washington, D.C., 2007), 379-91, 383.

123 Among the countries represented were Libya, Nigeria, Senegal, Niger, and Sierra Leone. Gil and de Graft-Johnson, Census, vol. V, 7.

${ }^{124}$ Economic Commission for Africa, Seminar on Population Problems in Africa, 29 Oct.-10 Nov. 1962, Cairo, United Arab Republic, "Training in Demographic Statistics and Research in Africa," 7-8.

${ }^{125}$ For example, the United Nations classified the information produced by the 1960 Ghana census as "rough data," overtaken by the colonial censuses of Uganda (1959) and Northern Rhodesia (1956). Statistical Office of the United Nations, Demographic Yearbook 1962, 17. On the other hand, the Ghanaian census was the first postcolonial count (and one of the relatively few) among the round of African censuses that were part of the 1960 World Population Census to 
Service regarded the 1960 census as an example of "improvements in data collection methods, objectives, scope and production of adequate and reliable demographic information."126 However, as rightly noted by Martha Lampland in her study of the falsification of statistics in communist Hungary, a focus on the veracity of numbers "obscures crucial social processes at the heart of modernizing practices." ${ }^{\prime 27}$ How did census propaganda shape the broader modernizing projects of trust building and state formation?

\section{CONCLUSIONS}

The education campaign did not lead to a complete disappearance of hostile reactions to census-taking. Sporadic manifestations occurred, for example, in enumeration areas "claimed by one or more chiefs to be under their jurisdiction," or typically involved either ethnic groups or foreigners with a history of difficult relationships with the Ghanaian government. ${ }^{128}$ While these occurrences might lead us to qualify the success of the census education campaign, we should note that all the localities that refused to be counted in the 1948 census were finally enumerated in 1960, while the census report proudly noted "the unprecedented public co-operation obtained for the national enumeration."129 Even considering that it remains extremely difficult to disentangle the specific effects of census propaganda from other elements that shaped the perceptions of the respondents - such as the hopes (and fears) associated with the first postcolonial government, or the legislative sanctions prescribed against those who refused to cooperate ${ }^{130}$ - the trajectory of census education

have met the basic United Nations criteria of universality, simultaneity, and defined territory. United Nations, Economic Commission for Africa, Methods and Problems, 21.

${ }_{126}$ Ghana Statistical Service, Population Data Analysis Reports. Volume 1: Socio-Economic and Demographic Trends Analysis (Accra, 2005), xv.

127 Martha Lampland, "False Numbers as Formalizing Practices," Social Studies of Science 40, 3 (2010): 377-404, 378.

${ }_{128}$ Gil and de Graft-Johnson, Census, vol. V, 196, 199. The census report stresses especially the lack of cooperation from Ewes in the Eastern Region and the Togolese in Accra. Both cases should be understood within the tense relationship between Ghana and Togo, which in turn derived from the repartition of German Togoland (where most Ewes were initially located), between British Togoland, French Togoland, and the Gold Coast after World War I. Following the rise of the Ewe unification movement that called for the creation of a separate Ewe state, the results of the 1956 United Nations referendum led to the incorporation of British Togoland within Ghana. For a concise introduction to the history of Ghana-Togo relations, and a fascinating historical ethnography on the Ghana-Togo border, see Paul Nugent, Smugglers, Secessionists \& Loyal Citizens on the Ghana-Togo Frontier: The Lie of Borderlands since 1914 (Athens, Oh., 2002).

${ }_{129}$ The list of the localities that refused to be enumerated in 1948 and were instead included in the 1960 count is scattered in Ghana Census Office, Census, vol. I: The Gazetteer: Alphabetical List, 33, 39, 55, 68, 70, 71, 104, 110, 124, 140, 223, 264, 279, 293, 375. Omaboe's quote comes from his "Preface," in Ghana Census Office, Census, vol. I, v.

130 Yet, I have not found evidence to support the claim that the 1950 Statistics Ordinance, prescribing fines up to $£ 25$ and/or three months of imprisonment for those who failed to provide the information requested without a valid reason, found a wide application. While the application of the 
in early independent Ghana helps refine our understanding of the "politics" of statistics.

Admittedly, there is nothing new in saying that statistics is "political." The point, though, is to understand how it is that ideas and practices underpinning the construction of statistical knowledge enter the political realm. The tale of the Census Education and Enlightenment campaign offers three main insights, related to the sites and the ways in which statistics inspire and inform processes of political imagination and transformation, to the concrete strategies employed by the postcolonial African state, and to the political embodiment of "development discourse." With reference to the first aspect, this study suggests that, far from being confined to statistical offices and the bureaucratic "center," the link between the construction of statistical knowledge and the process of imagining a nation-state can be mediated by other crucial sites of nation-making, like schools and the press. ${ }^{131} \mathrm{~A}$ focus on these sites implies a partial "shift" in the (physical and metaphorical) place of statistics in the process of statebuilding, zooming into the field, where the actual enumeration takes place and people's perceptions of the state directly affect the accuracy of the numbers produced. Seen through the lens of trust, the contribution of statistics to state-building stops being exclusively framed in terms of identification, classification, and quantification and becomes part of a wider set of cultural representations and political practices.

From the point of view of the literature on African state formation, this means that in order for the census to act as a political technology capable of accurately quantifying the state's potential wealth in people (in the form of accurate numbers) and actualizing it (in the form of political support), the education campaign had to inscribe the count within the narrative of a new social contract. This narrative revolved around exchanging people's cooperation with the promise of material progress, thus removing the census from the semantic spheres of taxation and surveillance that had hindered the colonial regime's capacity to provide an accurate population count. In light of the uneven political and institutional topography that typically characterizes African states, ${ }^{132}$ the census education campaign should be read as part of a larger struggle to

1961 Statistics Act, which replaced the 1950 ordinance, resulted in an enumerator being sentenced to nine months imprisonment at hard labor for fictitious enumeration, the census report reiterated that the emphasis was consistently on obtaining people's cooperation and support, Census, vol. $\mathrm{V}, 358$.

131 Latour, Science in Action.

132 Catherine Boone, Political Topographies of the African State: Territorial Authority and Institutional Choice (Cambridge, 2003). These features could have repercussions on the construction of statistical knowledge, as shown in Gerardo Serra, "An Uneven Statistical Topography: The Political Economy of Household Budget Surveys in Late Colonial Ghana, 1951-1957," in Morten Jerven, ed., "Measuring African Development: Past and Present," special issue of Canadian Journal of Development Studies/Revue canadienne d'études du développement 35, 1 (2014): 9-27. 
link the construction of statistical knowledge with the expansion and consolidation of the state's presence over its territory. ${ }^{133}$

By looking at the content of the representations emerging from the education campaign, we observed that in the few intense months preceding the enumeration the census stopped being exclusively framed in the technical or bureaucratic language stressed by Ferguson. ${ }^{134}$ Within that frame, the census would have been reduced to either a technocratic exercise of measurement necessary for national planning, or as an input in the United Nations' attempt to take a snapshot of the global population. Instead, the census entered the literary imagination, informing visions of a utopian future where poverty and illiteracy would be eradicated, as in the anonymous poem quoted at the beginning of this article. ${ }^{135}$ Census night was simultaneously inscribed into the country's memory as part of the epic of the country's victory against colonialism ("the second great night of Ghana after independence"), as the dawn of a bright postcolonial future, and as an occasion to invoke, through "traditional" dancing and drumming, the spirits of an "authentic" precolonial past. ${ }^{136}$ The creation of the numbers and figures on which the articulation of "development" as object of expert knowledge depended was the product of visual and narrative representations that could "re-politicize" the census by placing it at the center of broader discourses about the state. In contrast with Ferguson, then, we observe that the creation of statistics, which contribute to the "depoliticizing" capacity of "development discourse," can also depend on the articulation of narratives that perform the opposite operation.

This also raises questions about the ways in which the prescriptions of the "development apparatus" acquire new political meanings and connotations in the receiving contexts. The census campaign points at two very different channels. The school campaign captures the contested nature of the mobilization of

133 Accounts of other preparatory activities reinforce this view. For example, the Daily Graphic described the field teams dividing the country into enumeration areas as the men who "toiled in heatwave-swept districts of Northern Ghana and in the forests of Ashanti and Brong-Ahafo to demarcate enumeration areas within a time limit considered humanly impossible"; by "candle, torch and by cigarette lighter they worked in the vast fields of the north"; "more often than not" walking "10 miles in scorching heat." "A Lot of Work Went into the Preparations," Daily Graphic, 19 Mar. 1960: 5. The reform of the Ghanaian statistical apparatus also attributed a crucial role to the creation of a permanent and much larger field organization that could penetrate the country's most remote areas. Ghana Central Bureau of Statistics, Field Survey Work in the Ghana Statistics Office: Statistical and Economic Papers no. 8 (Accra, 1961).

134 Ferguson, Anti-Politics Machine.

135 "Hail the Census Night," Evening News, 19 Mar. 1960: 3.

136 Dove, "Remember," 3. The variety of iconographies, rhetorical strategies, and narrative structures developed as part of African census education campaigns can be further corroborated with the experience of the Liberian census in 1962. There, the attempt to explain the importance of the census to school children, and to represent the government as a benevolent and trustworthy entity, resulted in the invention of a delightful allegorical fable entitled "How Spider Helped Elephant Take Census." Republic of Liberia, Bureau of Economic Research and Statistics, The Population Census: Handbook of Census Education for Schools (Monrovia, 1961), Appendix D. 
children in Nkrumah's Ghana, which found justification in both the discourse built by the United Nations and in the authoritarian socialism that inspired the creation of the Young Pioneers. In the press, the census was presented as a tool of salvation and part of the syncretism characterizing the "applied religion" of Nkrumaism. ${ }^{137}$ From this perspective, the census became simply a temporary embellishment for the political theology built around Nkrumah. As a result of these two processes, the democratic message with which the United Nations infused the task of census-taking became incarnated in a much more ambivalent political world. The task of acquiring people's trust created the interstitial space between a view of the state as a benevolent entity depending on individual participation, a technocratic agent capable of complex operations of quantification, and a messianic personification in the dictator.

In conclusion, census education can represent a useful departure point from which to interrogate the complex ties linking trust, quantification, propaganda, and political imagination. Between the 1950s and 1960s, several countries in Asia, Africa, and Latin America designed population censuses explicitly in line with the United Nations standards and recommendations. ${ }^{138}$ With education campaigns becoming a potential juncture of the interface between state-building and transnational technocracy, there is certainly much scope for census propaganda to enrich our understanding of the place occupied by statistics in political imagination. Through further case studies and comparative analysis, a focus on census education can inform a political and cultural history of statistics that is more intimately connected with the tensions, visions, and dreams that are hidden beneath official numbers.

137 On the definition of "Nkrumaism" as "applied religion," see Kofi Baako's speech on "Nkrumaism-African Socialism: Ghana's Conception of Socialism," reprinted in Omari, Kwame Nkrumah, Appendix B, 194.

${ }^{138}$ As part of the 1950 World Population Census, countries as different as Canada, Pakistan and Paraguay developed census publicity programs. United Nations, Handbook, vol. 1, 85-86. African countries that undertook some forms of census publicity around 1960 included Egypt, Nigeria, Tanganyika, Uganda, Zanzibar, Kenya, and Liberia. United Nations Economic Commission for Africa, Methods and Problems, 40. 
Abstract: The article uses the first population census of postcolonial Ghana to analyze the relationship between statistics and the process of imagining the nation-state. In contrast with much historical and sociological literature, which conceptualizes the relationship between census-taking and state formation in terms of identification, classification, and quantification, the departure point of this analysis is the importance of gaining the trust of the counted subjects. In Ghana, where the possibility of obtaining accurate population returns had been severely hindered by people's distrust in the state, the 1960 population census saw the organization of a capillary education campaign in schools and in the press. By dissecting the iconographies emerging from the Census Education and Enlightenment Campaign, the article makes three contributions. First, it shows that understanding the concrete ways in which statistics inform political imagination requires an expansion of the field of observation beyond the statistical machinery and other "centers of calculation." Second, complementing James Ferguson's understanding of "development discourse" as an "anti-politics machine," it is argued that the possibility of making the people of Ghana "census minded" depended on the construction of a much richer set of inherently political representations about the nature of the postcolonial state. Finally, it shows the importance of critically interrogating the political implications acquired by the reception of global statistical practices. It does so by documenting the multiple ways in which the international standards promoted by the United Nations became entwined with the transformation of Ghanaian politics through the mobilization of children and press propaganda.

Key words: Ghana, state-building, census, trust, development, authoritarianism, population, political imagination, propaganda 